\title{
Spring grazing management and tiller dynamics in a ryegrass/white clover pasture
}

\author{
A. HERNANDEZ-GARAY, J. HODGSON and C. MATTHEW \\ Department of Plant Science, Massey University, Palmerston North
}

\begin{abstract}
The objective of this trial was to study the effect of variation in the timing and duration of lax spring grazing on tiller dynamics in perennial ryegrass. Tiller population density, tiller appearance, and tiller death were measured in a sward of perennial ryegrass (cv. Grasslands Nui) and white clover (cv. Grasslands Tahora) grazed by sheep every 14 days to $4 \mathrm{~cm}$ (hard) and every 21 days to $7 \mathrm{~cm}$ (lax) residues. The experiment comprised 2 lax spring grazing treatments [lax grazing October 26-December $8(\mathrm{H}-\mathrm{H}-\mathrm{L}-\mathrm{H})$ and September 16- December 8 (H-L-L-H)], plus a hard grazed control $(\mathrm{H}-\mathrm{H}-\mathrm{H}-\mathrm{H})$. Ryegrass tiller density was greater in $\mathrm{H}-\mathrm{L}-\mathrm{L}-\mathrm{H}$ than $\mathrm{H}-\mathrm{H}-\mathrm{L}-\mathrm{H}$ and $\mathrm{H}-\mathrm{H}-\mathrm{H}-\mathrm{H}$ from mid summer until the end of the trial in autumn, mainly because of the difference in tillering activity late in December. Tiller appearance rate increased in all the treatments from September to the end of January, and was particularly high late in December in the second regrowth after grazing of the apices of the main group of reproductive tillers. The lax grazing management strategy increased tiller appearance rate during late December and January. Higher tiller losses in lax grazing treatments over the same period were not offset enough to affect this advantage. The response in tiller population density was greater following the extended period of lax spring grazing.
\end{abstract}

Keywords: grazing management, Lolium perenne, reproductive growth, tiller population density, tiller demography, Trifolium repens

\section{Introduction}

Recent studies of tiller dynamics in ryegrass have revealed consistent seasonal patterns of tiller appearance and death, and also have demonstrated the potential advantages to tiller population and herbage production in late summer and autumn from a spring management which allows early seedhead development (Matthew et al. 1989, 1991; Matthew 1990; Da Silva et al. 1993). Matthew et al. (1989) suggested that a timely hard grazing of reproductive tillers may increase summer- autumn pasture growth rate by re-allocation of energy reserves to daughter tillers.

This experiment was carried out to study the effect of variation in the timing and duration of lax spring grazing on tiller dynamics and summer pasture production in perennial ryegrass. Only the results of observations on tiller activity and tiller demography are reported here.

\section{Material and methods}

The trial was conducted at Massey University between September 1992 and March 1993 on a perennial ryegrass (Lolium perenne, cv. Grasslands Nui) and white clover (Trifolium repens, cv. Grasslands Tahora) sward, which was rotationally grazed by sheep. The experiment comprised 2 lax spring grazing treatments [lax grazing 26 October-8 December (H-H-L-H) and 16 September8 December (H-L-L-H)], and a hard grazing control (H-H-H-H). Individual plots $9.3 \mathrm{~m} \mathrm{x} 9.3 \mathrm{~m}$ were grazed every 14 days to $4 \mathrm{~cm}$ (hard), or every 21 days to $7 \mathrm{~cm}$ (lax), and allocated in a complete randomised block design with 3 replicates. From 8 December on, all the treatments were grazed every 2 weeks to $4 \mathrm{~cm}$ (hard).

Tiller demography was measured at fortnightly intervals throughout the trial. Two $6.5 \mathrm{~cm}$ diameter plastic frames per plot were permanently fixed at ground level. All live ryegrass tillers within each frame were tagged on 18 September 1992 with short lengths of coloured split plastic tubing $(2-5 \mathrm{~mm}$ diam. and 3-5 $\mathrm{mm}$ long). New tillers were tagged at 2-week intervals, using a new colour each time. Rings were removed from dead tillers and counted. Estimation of tiller weight was made before and after each grazing from 3 groundlevel quadrat $(20 \mathrm{~cm}$ x $50 \mathrm{~cm})$ samples per plot. Tiller population density was determined from 30 cores (each $5.3 \mathrm{~cm}$ diameter) per plot throughout the experimental period.

\section{Results and discussion}

Tiller population density

Details of changes in ryegrass tiller population density are shown in Table 1 and Figure 1. The initial tiller population estimated over all treatments was 3500 tillers/ $\mathbf{m}^{2}$. Tillering was most rapid between November and January. A similar period of rapid tillering has been 
observed in New Zealand in swards under grazing (Chapman et al. 1983; Korte 1986; L'Huillier 1987; Matthew et al. 1989; da Silva et al. 1993) or cutting (Korte 1986).

Tiller densities were higher in fixed quadrats than in surrounding swards (Table 1 and Figure 1). This effect has been noted in previous studies (Davies 1981; Matthew et al. 1989), and appears to be associated with the sward disturbance involved in tiller counting. To minimise the biases involved, subsequent data on tiller appearance and loss (Table 3) are expressed on a tiller per tiller basis.

Table 1 Tiller density of ryegrass-white clover sward under contrasting spring grazing management (tillers $/ \mathrm{m}^{2}$ from tiller cores).

\begin{tabular}{|c|c|c|c|c|c|}
\hline Treatment & 20 ot & 1 Dec & 1 Jan & 25Jan & 23 Mar \\
\hline $\begin{array}{l}H-H-H-H \\
H-L-H-H \\
H-L-L-H \\
S E\end{array}$ & $\begin{array}{c}4690 \\
4530 \\
4770 \\
306\end{array}$ & $\begin{array}{c}3630 \\
3260 \\
3740 \\
466\end{array}$ & $\begin{array}{l}6990 \\
5640 \\
7070 \\
1115\end{array}$ & $\begin{array}{c}7760 \\
6620 \\
12740 \\
1636\end{array}$ & $\begin{array}{l}\mathbf{5 0 5 0} \\
8050 \\
7756 \\
1248\end{array}$ \\
\hline
\end{tabular}

From late December the tiller population density was higher in H-L-L-H than in H-H-L-H and H-H-H-H, and these differences persisted throughout the trial (Figure 1 and Table 1). Variability in estimates of tiller population density was high. However, within marked populations, tiller population density in H-L-L-H was $17 \%$ and $51 \%$ higher than H-H-H-H and H-H-L-H in late December, and $27 \%$ and $30 \%$ higher in late January (Figure 1). In tiller cores, tiller density in H-L-L-H was $64 \%(\mathrm{P}=0.06)$ and $44 \%(\mathrm{P}=0.12)$ higher than in H-H-H-H and H-H-L$\mathrm{H}$ respectively in late January and $59 \%(\mathrm{P}=0.15)$ higher than $\mathrm{H}-\mathrm{H}-\mathrm{H}-\mathrm{H}$ at the end of March.

Table 2 Effect of grazing treatment on mean tiller dry weight (mg) and relative proportion of vegetative and reproductive ryegrass tillers in early December.

\begin{tabular}{lcccc}
\hline & H-H-H-H & H-H-L-H & H-L-L-H & SEM \\
\hline Mean tiller weight & 16 & $\mathbf{3 6}$ & 29 & $3.03^{\prime}$ \\
$\%$ of vegetative and & reproductive tillers & & & \\
Vegetative & 64 & 67 & 67 & \\
Total Repr. & 16 & 33 & 33 \\
(a) No flag leaf & 14 & 17 & 23 \\
(b) Flag leaf expanded & 2 & 7 & 3 \\
(c) Seedhead & 0 & 9 & 7
\end{tabular}

Before the switch to common grazing management in early December the proportion of ryegrass tillers which were reproductive was twice as great in treatments H-H-L-H and H-L-L-H as in H-H-H-H (Table 2), and no tillers on treatment $\mathrm{H}-\mathrm{H}-\mathrm{H}-\mathrm{H}$ carried emerged seedhead at that time. Individual tiller weight was also twice as great on the two lax grazed treatments as on the control (Table 2). Hard grazing increased the proportion of other grasses and weeds and reduced the proportions of ryegrass and white clover in the pastures in early December (52, $\mathbf{6 6}$ and $67 \%$ for ryegrass and $\mathbf{8 , 1 2}$ and $11 \%$ for clover in treatments $\mathrm{H}-\mathrm{H}-\mathrm{H}-\mathrm{H}, \mathrm{H}-\mathrm{H}-\mathrm{L}-\mathrm{H}$ and H-L-L-H, respectively).

\section{Tiller appearance and loss}

Tiller appearance and loss occurred throughout the experiment, but were particularly high in late spring and summer (Figure 1 and Table 3). Figure 1 shows continuing increase in tiller density in all treatments from September to the end of January, with particularly rapid tillering activity late in December.

Stem elongation started late October in all the treatments. During this period tiller appearance was not significantly different between treatments $(\mathrm{P}>0.05)$, but lax spring grazing resulted in the peak of tiller appearance being later and greater than that under continued hard grazing. Thus, tiller appearance rate (tiller per tiller per 14 days) was $100 \%$ and $50 \%$ higher in $\mathrm{H}-\mathrm{H}-\mathrm{H}-\mathrm{H}$ than $\mathrm{H}-\mathrm{H}-\mathrm{L}-\mathrm{H}$ and $\mathrm{H}-\mathrm{L}-\mathrm{L}-\mathrm{H}$, respectively in late November $(\mathrm{P}<0.05)$, but the difference was reversed $(\mathrm{P}<0.05)$ in late December. No other treatment effects were significant. The burst of tillering activity in December represented increases of $35 \%, 48 \%$ and $60 \%$ over the late November tiller population density in treatments $\mathrm{H}-\mathrm{H}-\mathrm{H}-\mathrm{H}, \mathrm{H}-\mathrm{H}-\mathrm{L}-\mathrm{H}$ and $\mathrm{H}-\mathrm{L}-\mathrm{L}-\mathrm{H}$ respectively.

Table 3 Tiller appearance and motality under contrasting spring grazing management (tillers/tiller/14 days).

\begin{tabular}{lcccccr}
\hline Treatment & \multicolumn{2}{c}{31 Nov } & \multicolumn{2}{c}{ 15 Dec } & \multicolumn{2}{c}{31 Dec } \\
& App & Los & App & Loss & App & Lo s s \\
\hline H-H-H-H & 0.46 & 0.35 & 0.26 & 0.12 & 0.52 & 0.10 \\
H-L-H-H & 0.35 & 0.19 & 0.26 & 0.26 & 0.75 & 0.25 \\
H-L-L-H & 0.20 & 0.21 & 0.13 & 0.22 & 1.10 & 0.25 \\
SE & 0.09 & 0.06 & 0.07 & 0.03 & 0.20 & 0.04 \\
\hline
\end{tabular}

The high rate of tiller appearance found particularly in treatment H-L-L-H supports the result of Matthew et al. (1989) and the conclusion (Matthew et al. 1991) that the early growth of young summer tillers can be stimulated by the transfer of assimilates from decapitated flowering tillers.

The highest rate of tiller appearance in $\mathbf{H}-\mathbf{L}-\mathbf{L}-\mathbf{H}$ and $\mathrm{H}-\mathrm{H}-\mathrm{L}-\mathrm{H}$ was recorded in the second regrowth after defoliation of the apices of the main group of reproductive tillers. After the main period of activity late in November and December, differences in tiller 
appearance were not significant. Korte (1986) recorded highest tiller appearance rate in November, in the regrowth immediately after defoliation of the main group of reproductive tillers. The differences between our results and those of Korte could have been due to differences in the frequency of defoliation; a 2-week interval was used in our trial, and a 3-week interval in that of Korte (1986).

L'Hullier (1987) found that during summer and autumn high stocking rate resulted in higher tiller densities and content of white clover than low stocking rate. Other studies have concluded that tillering was not influenced by grazing intensity or cutting frequency (Tallowin 1981; Chapman et al., 1983; Korte, 1986). However, our results indicate that relatively lax grazing management prior to and during the reproductive phase increased both tiller appearance and tiller population in summer (Figure 1 and Table 3).

Tiller losses were highest in November and December, similar to the seasonal patterns observed by L'Hullier (1987) in dairy pastures. Of the original population of overwintering tillers, $77 \%$ were lost from treatment $\mathrm{H}-\mathrm{H}-\mathrm{H}-\mathrm{H}$ by late December and a further $7 \%$ by the end of the trial. Losses on treatments H-H-L-H and H-L-L-H were $65 \%$ and $70 \%$ to late December, and $20 \%$ of the original tillers on these treatments survived to the end of March (Figure 1).

Tiller mortality expressed as tillers per tiller per 14 days in $\mathrm{H}-\mathrm{H}-\mathrm{H}-\mathrm{H}$ was $84 \%$ and $66 \%$ higher than in $\mathbf{H}$ H-L-H and H-L-L-H in November $(\mathrm{P}<0.05$, Table 3$)$. During December the reverse was the case, losses being $132 \%$ and $114 \%$ higher in H-H-L-H and in H-L-L-H than in $\mathrm{H}-\mathrm{H}-\mathrm{H}-\mathrm{H}(\mathrm{P}<0.05)$. Death of reproductive tillers contributed to losses in the two previously lax grazed treatments over this period. From the populations of tillers tagged in the peak of tillering activity in December, $64 \%, 48 \%$ and $51 \%$ had disappeared by late March from treatments H-L-L-H, H-H-L-H and $\mathbf{H}-\mathbf{H}$ $\mathrm{H}-\mathrm{H}, \quad$ respectively.

\section{Conclusions}

The results of this study confirm the hypothesis (Matthew et al. 1989, 1991) that enhanced levels of summer pasture production after a period of relatively lax spring grazing management and subsequent removal of early seedheads are a consequence of increased tillering activity after the control grazing. They show that although this enhancement of tillering activity is short lived and is followed by increases in rates of tiller loss, the net advantage in tiller population density can persist for some time. The evidence also indicates for the first time that this effect is likely to be greater after an extended period of relatively lax spring grazing.
Figure 1 Changes in tiller population and tiller age profiles for ryegrass clover sward under contrasting spring grazing managements. Shaded sectors indicate time trends in the population of tillers present at the start of the experiment, and those appearing in successive two-' week recording intervals.

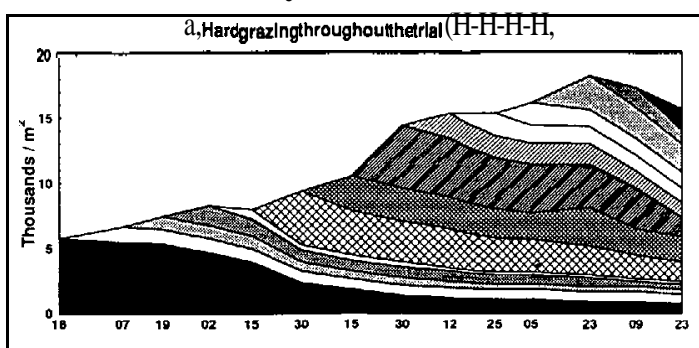

b) Lax grazing late In October to early December (H-H-L-H)

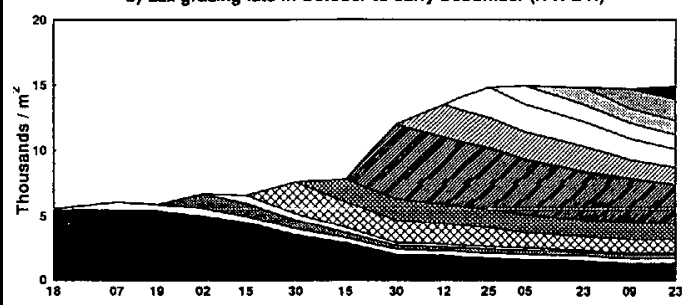

c) Lax grazing late September to early December (H-L-L-H)

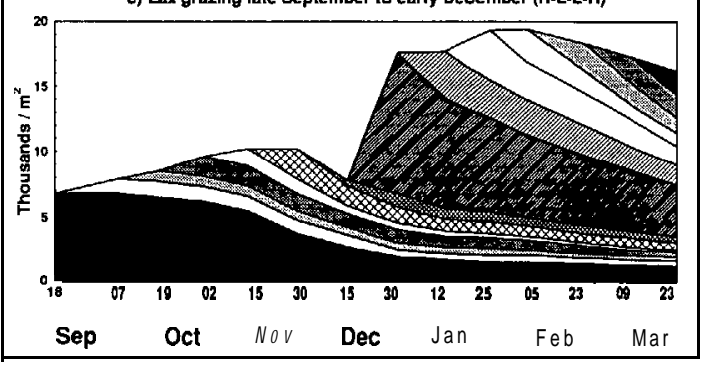

\section{ACKNOW LEDGEMENTS}

We thank the Ministry of Foreign Affairs and Trade of New Zealand and the Colegio de Postgraduados, of Montecillos Mexico for their financial support; Mr. Terry Lynch, Mrs. Sheralee Cleland, Mr. Mark Osborne and Mr. Gary Evans for their generous help during the trial period. The technical assistance of Miss Frith Brown and Mrs Cally McKenzie are also much appreciated.

\section{REFERENCES}

Chapman, D.F.; Clark, D.A.; Land, C.A.; Dynock, N. 1983. Leaf and tiller growth of Lolium perenne and Agrostis spp. and leaf appearance rates of Trifolium repens in set-stoked and rotationally grazed hill pastures. New Zealand journal of agricultural research 26: 159- 168. 
Da Silva, S.C.; Matthew, C.; Matthews, P.N.P.; Hodgson, J. 1993. The influence of spring grazing management on summer and autumn production in dairy pastures, Proceedings of the XVII International Grassland: 859-860.

Davies, A. 1981. Tissue turnover in the sward. In Sward measurement handbook, J. Hodgson, R.D. Baker, Alison Davies, A.S.Laidlaw, J.D. Leavereds. British Grassland Society, Hurley.

Korte, C.J. 1986. Tillering in 'Grasslands Nui' perennial ryegrass swards. 2. Seasonal pattern of tillering and age of flowering tillers with two mowing frequencies. New Zealand journal of agricultural research 29: 629-638.

L'Hullier, P.J. 1987. Tiller appearance and death of Lolium perenne in mixed swards grazed by dairy cattle at two stocking rates. New Zealand journal of agricultural research 30: 14-22.

Matthew, C. 1990. Translocation from flowering to daughter tillers in perennial ryegrass (Lolium perenne L.). Agronomy Department, Massey University Internal Report.

Matthew, C.; Xia, J.X.; Hodgson, J.; Chu, A.C.P. 1989.

Effect of late spring grazing management on tiller age profiles and summer-autumn pasture growth rates in perennial ryegrass (Lolium perenne L.) sward. Proceedings of the XVI International Grassland Congress: 521-522.

Matthew, C.; Chu, A.C.P.; Hodgson, J.; MacKay, A.D. 1991. Early summer pasture control: What suits the plant?. Proceedings of the New Zealand Grassland Association 53: 73-79.

Tallowin, J.R.B. 1981. Aninterpretation of tiller number changes under grazing. pp. 78-80 In Plant physiology and herbage production. Wright, C.E. ed., Occasional symposium of the British Grassland Society 13 